\title{
Ceviz Ezmesi ve Dut Kurusu Tozu İlavesiyle Üretilen Düşük Kalorili Dondurmanın Bazı Kalite Niteliklerinin Belirlenmesi
}

\author{
Ayla ARSLANER* Mehmet Ali SALIK \\ Bayburt Üniversitesi Mühendislik Fakültesi Gıda Mühendisliği Bölümü, 69000, Bayburt, \\ (*Sorumlu yazar e-mail:aylaarslaner@bayburt.edu.tr)
}

Geliş Tarihi : 19.01.2017

Kabul Tarihi :13.02.2017

\begin{abstract}
ÖZET : Bu çalışmanın amacı; fonksiyonel özellikleri geliştirilmiş, besleyici değeri yüksek ve kalori değeri düşük bir dondurma üretimi gerçekleştirmektir. Bu amaçla dondurma üretiminde dondurma miksine sakkaroz yerine doğal tatlandırıcı olarak $200 \mathrm{~g} / \mathrm{kg}$ oranında kuru dut tozu ve kremaya ikame olarak $50 \mathrm{~g} / \mathrm{kg}$ oranında ceviz ezmesi ilave edilmiştir. Üretilen dondurmanın bazı fiziksel, kimyasal, mikrobiyolojik ve duyusal kalite nitelikleri üzerine kuru dut tozu ve ceviz ezmesi kullanımının etkisi araștırılmıștır. Araştırmada dondurma üretiminde dut kurusu tozu ve ceviz ezmesi ilavesinin kurumadde, protein, kül ve hacim artışı oranını arttırdı̆̆ ve kalori değerinde azalmaya neden olduğu, ayrıca dondurmada karakteristik bir tat-aroma ve renk oluşumu sağladığı tespit edilmiştir. Dondurma örnekleri, tüm duyusal parametreler bakımından standartlarda belirtilen sınırın üzerinde puan almıştır. Mikrobiyolojik analiz sonuçları, dondurma örneklerinin bakteriyolojik kalitesinin yüksek olduğunu ve üretim sonrasında herhangi bir bulaşmanın söz konusu olmadığını göstermektedir.
\end{abstract}

Anahtar kelimeler: Dondurma, ceviz, dut, fonksiyonel özellik, kalori

Determination of Some Quality Properties of Low Calorie Ice-Cream Produced with Walnut Paste and Dried Mulberry Powder

\begin{abstract}
The aim of this study is to realize to produce an ice-cream which of some functional properties was improved and that has high nutritional value, low calorific value. In this context, dry mulberry powder $(200 \mathrm{~g} / \mathrm{kg})$ was used as a source of substituent and natural sweeteners instead of sucrose in ice-cream production. And walnut $(50 \mathrm{~g} / \mathrm{kg})$ was used as a substituent of butter instead of cream. The effects of using dry mulberry and walnut some qualities of the ice cream produced were also investigated. According to the analysis results; dry mulberry powder and walnut paste using in ice-cream producing helped to improve the rate of dry matter, protein, ash, the increase in overrun values and to reduce calorie of the ice-cream. Also it was seen that it is useful to form characteristic taste and aroma an even color formation in an ice-cream. The ice-cream samples were scored over the specified limits in the standards for all sensory parameters. The results of microbiological analysis showed that the bacteriological quality of the ice cream samples was high and there was no contamination after production.
\end{abstract}

Keywords: Ice cream, walnut, mulberry, functional property, calorie

\section{GÍRIŞ̧}

Dondurma; süt ve yağsız süt kurumaddesi, krema, şeker, stabilizatör, emülgatör maddeler yanı sıra amaca uygun olarak miksinde kuru ve yaș meyveler, fonksiyonel diyet lifleri, probiyotik mikroorganizmalar, prebiyotik bileşenler ve tatlandirıcilar bulundurabilen, geleneksel ve endüstriyel metotlarla elde edilmiş formları bulunan karmaşık fizikokimyasal sisteme sahip bir süt üründür.

Çocuklar ve gençler başta olmak üzere toplumun her kesimi tarafindan, yılın her döneminde zevkle tüketilen dondurma, süt yağı, protein, kalsiyum, fosfor ve diğer mineraller bakımından zengin bileşime sahiptir (Goff vd., 1999). Dondurma miksine tatll11k vermek amaciyla ilave edilen şeker, yağlılığ1 dengelemesi, ürünün yapı ve kitlesini de düzeltmesi yanı sıra ucuz bir kurumadde kaynağıdır (Sarığlu Yavaş, 2015). Dondurma sakkarozu yüksek oranda (\%18-25) içermesi (Alkan ve Gültekin, 1996) ve yüksek enerji değerine sahip besin bileşenlerini (şeker, protein ve yağ) yapısında bulundurması nedeniyle kalori değeri oldukça yüksek bir süt ürünüdür.
Fonksiyonel gidalar 5179 sayılı Türk Gida Kanununa göre, besleyici etkilerinin yanı sıra bir ya da daha fazla etkili bileşene bağlı olarak sağlı̆̆ koruyucu, düzeltici ve/veya hastalık riskini azaltıcı etkiye sahip olup bu etkileri bilimsel ve klinik olarak ispatlanmış gıdalar olarak tanımlanmaktadır (Anonim, 2004). Bir gida maddesinde bulunmas1 gereken tüm özelliklere sahip olan süte; omega-3 yağ asitleri, $\beta$-galaktozidaz, konjuge linoleik asit fenolik maddeler gibi antioksidan aktiviteye sahip bileşenler, gıda lifi, çeşitli vitamin ve mineral gibi katkıların ilavesiyle elde edilen fonksiyonel süt ürünleri, fonksiyonel gıda yaklaşımında çok önemli bir paya sahiptir.

Diyabet, kardiyovasküler hastalıklar, obezite gibi metabolik bozuklukların görülme sıklığının şekerin aşırı tüketimine bağlı olarak arttığı bildirilmektedir (Özdemir vd., 2015). Burada bahsi geçen şeker çoğunlukla endüstriyel gıdaların üretiminde kullanılan rafine şekerdir. Sakkaroz alternatifli tatlandırıcıların dondurma üretiminde kullanılması doğal ve beslenme açısından dengeli gıdalara odaklanan modern tüketicilerin 
gereksinimlerini karşılayabilir (Moriano ve Alamprese, 2017). Düşük kalorili gıdalar için tüketici talepleri arttıkça, alternatif tatlandırıcı ile yapılan ürünler son y1llarda daha popüler hale gelmiştir.

Dut, şeker oranının yüksekliği ile dikkat çeken bir meyvedir. Dut kurusu örneklerindeki ortalama toplam şeker oranının \%72.71 ile \%80.23 arasında; glikoz, fruktoz ve sakkaroz oranının ise sirası ile \%34.22-38.26, \%36.89-40.78 ve \%0.68-2.39 arasinda olduğu belirtilmiştir (Bakkalbaşı vd., 2004).

Ceviz, besin değeri yönünden oldukça zengin, sert kabuklu bir meyve türüdür. Yağ ve protein bakımından zengin bileşime sahip olan cevizin yağ içeriği çeşitlere ve tiplere göre \%50-77 arasında değişmektedir. $100 \mathrm{~g}$ yenilebilir iç ceviz yaklaşık 14 g protein içerir (Colombini vd., 1979; Özrenk vd., 2005). Özrenk vd. (2005) Erzincan yöresinden selekte ettikleri 25 ceviz örneğinde kül oranının ortalama \%1.69-2.24 arasında değiştiğini bildirmişlerdir. Ceviz, bileşiminde bulunan mineral maddeler, polifenolik bileşikler, bitkisel steroller, çoklu doymamış yağ asitleri özellikle de omega-3 ve omega-6 yağ asitleri nedeniyle fonksiyonel bir gidadır (Yiğit vd., 2005).

$\mathrm{Bu}$ çalışmada, ceviz ezmesi ve kuru dut tozu ilavesi ile dondurmanın fonksiyonel özelliklerinin geliştirilmesinin yanında, düşük kalorili dondurma üretimi hedeflenmiş; yağ ve şeker ikamesi olarak kullanılan bu bileşenlerin dondurmaların kalite niteliklerine etkisi araştırılmıştır.

\section{MATERYAL VE YÖNTEM}

\section{Materyal}

Dondurma üretiminde Bayburt piyasasından temin edilen pastörize inek sütü kullanılmıştır. Yağsız süt tozu Pınar Süt Mamülleri San. A.Ş. (İzmir)' den, dut kurusu ve ceviz Erzincan piyasasından, salep ise Burdur piyasasından temin edilmiştir. Miks bileşimine giren hammaddelere ait bazı fizikokimyasal ve mikrobiyolojik nitelikler Çizelge 1' de verilmiştir.

Dut kurusu tozu dondurma üretiminde miske sakkaroz ikamesi olarak, tipik sade dondurma bileşimindeki sakkaroz oranı (\%18-25) ve şeker analizlerinden elde edilen veriler doğrultusunda hesaplanan tatlılık oranı göz önünde bulundurularak ilave edilmiştir. Ceviz ise dondurma üretiminde krema yerine az yağlı dondurma kompozisyonunu (IDFA, 2016) sağlayacak şekilde yă̆ ikame edici olarak kullanılmıştır. Dut ve ceviz Bayburt Üniversitesi Mühendislik Fakültesi Gıda Mühendisliği Bölümü Laboratuvarında mikse ilave edilmeden önce öğütülmüş ve pastörize edilmiştir.

Çizelge 1. Dondurma üretiminde kullanılan hammaddelerin bazı özelliklerine ait ortalama değerler

\begin{tabular}{|c|c|c|c|c|}
\hline $\begin{array}{c}\text { Fiziko-kimyasal } \\
\text { Analizler }\end{array}$ & $\begin{array}{c}\text { Pastörize İnek } \\
\text { Süitü }\end{array}$ & Yağsız Süt Tozu & $\begin{array}{l}\text { Pastörize Dut } \\
\text { Kurusu Tozu }\end{array}$ & $\begin{array}{c}\text { Pastörize Ceviz } \\
\text { Ezmesi }\end{array}$ \\
\hline $\mathrm{pH}$ & $6.655 \pm 0.010$ & $6.750 \pm 0.000$ & $5.895 \pm 0.010$ & $6.403 \pm 0.005$ \\
\hline Titrasyon Asitliği (\%) & $0.1375 \pm 0.003$ & $0.1015 \pm 0.005$ & $0.9580^{\mathrm{a}} \pm 0.000$ & - \\
\hline Kurumadde $(\%)$ & $8.098 \pm 0.057$ & $95.577 \pm 0.058$ & $93.312 \pm 0.156$ & $95.656 \pm 0.208$ \\
\hline Kül $(\%)$ & - & - & $1.487 \pm 0.034$ & $2.150 \pm 0.003$ \\
\hline Protein $(\%)$ & $3.100 \pm 0.000$ & $36.000 \pm 0.000$ & $2.764 \pm 0.064$ & $14.316 \pm 0.032$ \\
\hline Yağ $(\%)$ & 0.15 & 1.25 & - & $61.55 \pm 1.800$ \\
\hline Toplam Şeker & - & - & $78.197 \pm 0.679$ & - \\
\hline İnvert Şeker & - & - & $70.426 \pm 1.101$ & - \\
\hline Sakkaroz & - & - & $7.382 \pm 1.690$ & - \\
\hline$L^{*}$ & - & - & $48.03 \pm 4.34$ & - \\
\hline$a^{*}$ & - & - & $1.55 \pm 0.15$ & - \\
\hline$b^{*}$ & - & - & $14.78 \pm 1.29$ & - \\
\hline $\begin{array}{c}\text { Mikrobiyolojik } \\
\text { Analizler (log kob/g) }\end{array}$ & $\begin{array}{l}\text { Pastörize İnek } \\
\text { Sütü }\end{array}$ & Yağsız Süt Tozu & $\begin{array}{l}\text { Pastörize Dut } \\
\text { Kurusu Tozu }\end{array}$ & $\begin{array}{c}\text { Pastörize Ceviz } \\
\text { Ezmesi }\end{array}$ \\
\hline TAMB & 2.699 & 4.201 & 3.041 & 3.980 \\
\hline Maya-Küf & $<1$ & $<1$ & $<1$ & $<1$ \\
\hline Koliform & $<1$ & $<1$ & $<1$ & $<1$ \\
\hline E.coli & - & - & - & $<1$ \\
\hline Staphylococcus aureus & - & - & - & $<1$ \\
\hline
\end{tabular}

${ }^{\mathrm{a}}$ susuz sitrik asit cinsinden titrasyon asitliği 
Yöntem

Dondurma Miksinin Hazırlanması ve Dondurma Üretimi

Dondurma örneklerinin üretimi, aşağıda verilen akış şemasına göre gerçekleştirilmiştir (Şekil 1). Mikse ilave edilecek bileşenler $1285 \mathrm{~g}$ miks ağırlığ üzerinden hassas bir şekilde hesaplanmıştır (Özdemir vd., 2015).
Dondurma makinesinden çıkan dondurma steril polipropilen kaplara (100 $\mathrm{mL})$ alınarak, analiz yapılıncaya kadar $-22{ }^{\circ} \mathrm{C}$ ' de muhafaza edilmiştir. Dondurma üretimi iki tekerrürde gerçekleştirilmiş olup, dondurma örneklerinde analizler 4 paralelli olarak yürütülmüştür.

Şekil 1. Dondurma üretim akış şeması

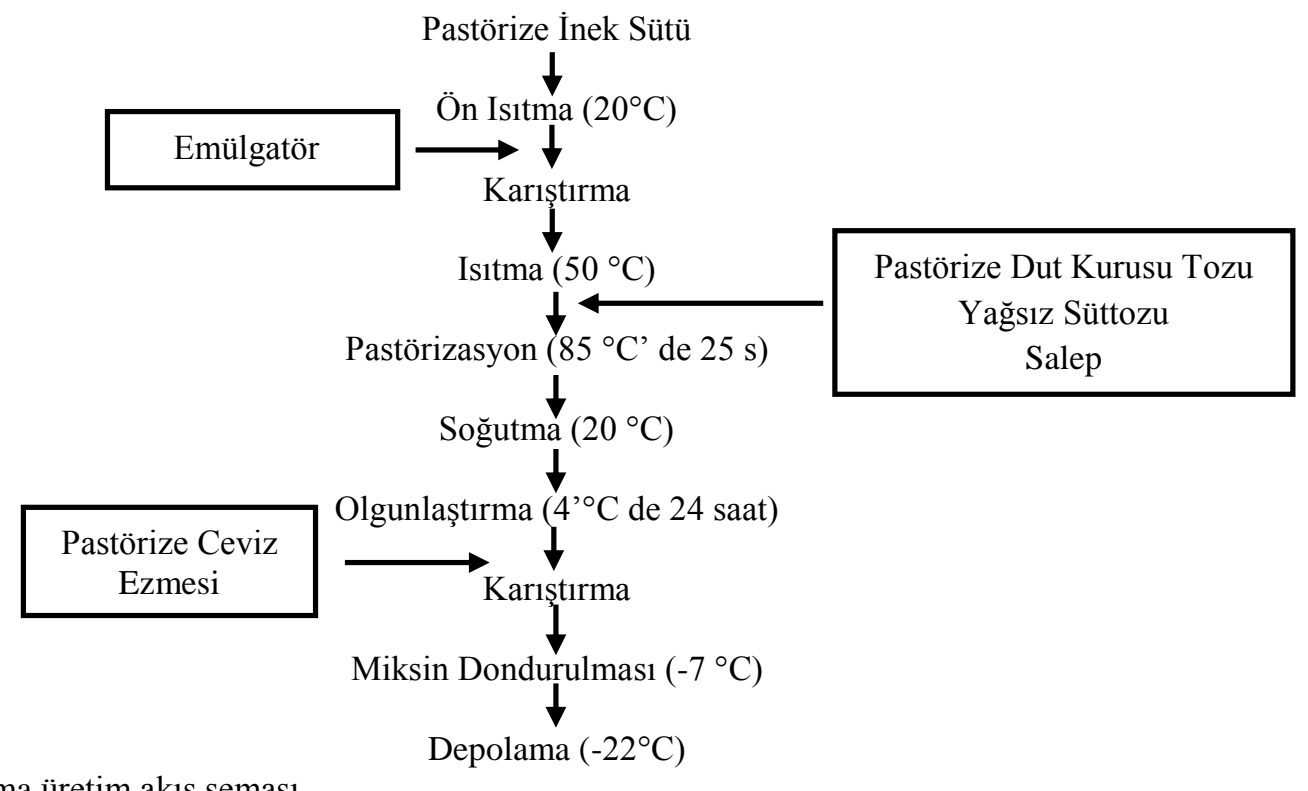

\section{Dondurma Örneklerinde Yapılan Fizikokimyasal Analizler}

Dondurma örneklerinde $\mathrm{pH}$ tayini, $\mathrm{pH}$ metre (Seven Compact pH/Ionmeter S220, Mettler Toledo) kullanılarak oda sıcaklığında tespit edilmiştir. Kurumadde ve yağ tayini Kurt vd., (2012)'ye göre; protein miktarı Kjeldahl yöntemi ile (IDF, 1993); şeker miktarı Lane- Eynon yöntemi ile (Metin, 2012); titrasyon asitliği Yöney (1968)'e göre; kül oranı Kurt (1990)'a göre tespit edilmiştir. Dondurma miksinde viskozite, viskozimetre (Brookfield DV-II Model) cihazı kullanılarak $4^{\circ} \mathrm{C}$ de $50 \quad$ rpm'de belirlenmiştir. Okunan değerler centipoise (cP) olarak ifade edilmiştir.

Dondurma örneklerinin ilk damlama süresi ve tamamen erime oranı tayininde; $10 \mathrm{~g}$ dondurma örneği darası alınmış kaplar üzerindeki tel süzgüye $(0.2 \mathrm{cmx} 0.2 \mathrm{~cm}$ gözenek ebatl1) konularak oda sıcaklığında (ortalama $20^{\circ} \mathrm{C}$ ) erimeye birakılmıştır. Dondurmaların eriyip ilk damlaların düştüğü süre belirlenmiştir. Ayrıca 30. ve 60. dakikalarda dondurma örneklerinin eriyen kısımları tartılarak, erime oranı aşağıdaki formülle hesaplanmıştır (Cotrell vd., 1979):

Erime oranı $\quad(\%)=[($ Eriyen $\quad k 1 s m ı n$ ağırlığg/Dondurmanın ağırlığı)] x100
Dondurma örneklerinin hacim artışı (overrun) oranı tayininde; darası belirlenmiş ölçülü silindir içerisine belirli hacme kadar dondurma, boşluk kalmayacak şekilde doldurulmuş ve analitik terazide tartılmıştır. Aynı dondurma numunesi bir beher içerisine konularak su banyosunda eritilmiştir. Eriyen karışım, ölçülü silindire aynı hacme kadar aktarılıp tartılmıştır. Hacim artışı aşağıdaki formülle hesaplanmıştır (Metin, 2012):

Hacim artıșı oranı $(\%)=[($ Dondurmanın hacmi Erimiş Dondurmanın Hacmi)/Erimiş Dondurmanın Hacmi] x 100

Dondurma örneklerinde renk tayini kolorimetre (Model CR 300, Chromometer, Minolta, Japan) cihazı kullanılarak belirlenmiştir. Elde edilen sonuçlar; $L^{*}$ (parlaklık; 100; beyaz, 0 ; siyah), $a^{*}$ (kırmızılık; \pm , kırmızı; -, yeşil), $b^{*}$ (sarılık; \pm , sarı; ,mavi) parametrelerine göre değerlendirilmiştir (Temiz ve Yeşilsu, 2010).

Dondurma örneklerinin toplam kalorisi, aşağıdaki formülle belirlenmiştir (Arbuckle, 1986):

Toplam Kalori: \%karbonhidrat x 3.87+ \%yağ x $8.79+\%$ protein $\mathrm{x} 4.27$ 


\section{Dondurma Örneklerinde Yapılan Mikrobiyolojik Analizler}

Steril polipropilen kaplara alınan dondurma örneklerinden steril şartlarda stomacher torbalarının içerisine $10 \mathrm{~g}$ örnek tartılmış ve üzerine $90 \mathrm{ml}$ steril fizyolojik tuzlu su $(\% 0.85 \mathrm{NaCl})$ ilave edilmiştir. Daha sonra Stomacher cihazında (Interscience Bag Mixer® 400 France) 2 dakika homojenize edilmiştir.

Dondurma örneklerindeki toplam aerobik mezofilik bakteri sayımı (TAMB) Plate Count Agar (PCA-Merck) $\left(30-32^{\circ} \mathrm{C}^{\prime}\right.$ de 48 saat), koliform grubu bakteri sayımı Violet Red Bile Agar (VRBA-Merck) (35-37 ${ }^{\circ} \mathrm{C}^{\prime}$ de 24 saat) (Harrigan, 1998); maya ve küf sayımı Potato Dextrose Agar (PDA-Merck) $\left(25^{\circ} \mathrm{C}\right.$ 'de 3-5 gün) (Pereira vd., 2008); Escherichia coli sayımı Chromocult Tryptone Bile X Glucuronide Agar (CTBX-Merck) $\left(44^{\circ} \mathrm{C}^{\prime}\right.$ de 24 saat) (Merck, 2005); Staphylococus aureus sayımı Baird Parker Agar (BPA-Merck) $\left(37^{\circ} \mathrm{C}^{\prime}\right.$ de 24 saat) (Tatini vd.,1984; Pichhardt, 2004) kullanılarak belirlenmiştir. Elde edilen sonuçlar log kob/g cinsinden ifade edilmiştir. $\begin{array}{lccc}\text { Dondurma } & \text { Örneklerinde } & \text { Yapılan } & \text { Duyusal } \\ \text { Analizler } & & \\ \text { Dondurma } & \text { örneklerinin } & \text { duyusal }\end{array}$ değerlendirmesi 8 kişilik bir panelist grup tarafindan gerçekleştirilmiştir. Panelistler, gıdaların duyusal analizinde tecrübe sahibi olan Bayburt Üniversitesi Gıda Mühendisliği Bölümü öğretim elemanlarından oluşturulmuştur. Panelistler dondurma örneklerini renk ve görünüş, yapı ve kıvam, tat ve koku, buzlu yapı, ağızda erime ve sakızımsılık özelliklerine göre 5 puan üzerinden değerlendirmişlerdir (Bodyfelt vd., 1988).

ARAŞTIRMA BULGULARI ve TARTIŞMA

Dondurmanın bazı fiziksel ve kimyasal özelliklerine ilişkin elde edilen ortalama değerler Çizelge 2'de verilmiştir. Dondurma örneklerinin ortalama kurumadde, yağ, toplam protein, kül değerleri sırasi ile $\% 31.593, \% 2.00, \% 4.305$ ve $\% 1.327$ olarak tespit edilmiştir. Dondurma örneklerinin ortalama $\mathrm{pH}$ değeri 6.31 , \%laktik asit oranı ise $\% 0.338$ olarak bulunmuştur.

Çizelge 2. Dondurma örneklerinin bazı fiziksel ve kimyasal özelliklerine ait ortalama değerler

\begin{tabular}{|c|c|c|c|c|c|c|c|c|c|c|}
\hline & \multirow{2}{*}{$\begin{array}{l}\text { KM } \\
(\%)\end{array}$} & \multirow{2}{*}{$\begin{array}{l}\text { Yăg } \\
(\%)\end{array}$} & \multirow{2}{*}{$\begin{array}{l}\text { Toplam } \\
\text { Protein }\end{array}$} & \multirow{2}{*}{$\begin{array}{l}\text { Kül } \\
(\%)\end{array}$} & \multirow[b]{2}{*}{$\mathbf{p H}$} & \multirow{2}{*}{$\begin{array}{c}\text { Laktik } \\
\text { Asit } \\
(\%) \\
\end{array}$} & \multicolumn{3}{|c|}{ Şeker (\%) } & \multirow{2}{*}{$\begin{array}{c}\text { Kalori* } \\
\text { (kcal) }\end{array}$} \\
\hline & & & & & & & Toplam & İnvert & Sakkaroz & \\
\hline ORT & 31.593 & 2.00 & 4.305 & 1.327 & 6.31 & 0.338 & 17.495 & 15.559 & 1.914 & 103.67 \\
\hline SD & 0.163 & 0.00 & 0.045 & 0.008 & 0.00 & 0.012 & 0.372 & 0.076 & 0.287 & - \\
\hline
\end{tabular}

*\%karbonhidrat x 3.87+ \%yağ x 8.79 + \%protein x 4.27 formülü kullanılarak hesaplanmıştır.

Sade dondurma örneklerinin fiziksel ve kimyasal özelliklerine ait literatürlerden elde edilen ortalama bulgular Çizelge 3'de verilmiştir. Dondurma örneklerinin ortalama kuru madde oranı Özdemir vd. (2015), Kırmacı vd. (2014), Kesenkaş vd. (2013), Erkaya vd. (2012), Temiz ve Yeşilsu (2010) ve Badem (2006) tarafindan sade dondurmalarda tespit edilen değerlerin üzerinde bulunmuştur. Dondurma miksinde kurumadde oranının ortalama \%18-25'ini karşılayan sakkaroz (Alkan ve Gültekin, 1996) yerine bu çalı̧̧mada dut kurusu tozu kullanılmış ve dondurma örneklerinin kurumadde oranı Türk Gida Kodeksi Dondurma Tebliği'nin öngördüğü yağsız kurumadde (\%28) sınırının üzerinde (\%29.593) bulunmuştur.

Dondurma örneklerinin yă oranı ortalama \%2.00 dir. Bu değer, Türk Gıda Kodeksi Dondurma Tebliği'nde yarım yağlı dondurma için belirtilen (en az \%3) orandan düşük olmakla birlikte, FDA (Food and Drug Administration)'ya göre az yağlı dondurma sınıfına girmektedir (IDFA, 2016). Yağ oran1 azaltılmış süt ve süt ürünleri özellikle kilo problemli, kronik kalp ve damar hastalıkları bulunan, kan kolesterol seviyesi yüksek ve diyetinde enerji alımına dikkat eden bireyler tarafindan tercih edilmekte; beslenme otoriteleri, günlük diyetle alınan enerjinin yağdan gelen kısmının \%30'u aşmaması gerektiğini belirtmektedir (Baysal, 2009).

Dut kurusu tozu ve ceviz ezmesi ilavesi ile üretilen dondurma örneklerinin protein değeri ortalama \%4.305 olarak belirlenmiştir. $\mathrm{Bu}$ oran Dervişoğlu vd. (2004), Aliyev (2006), Badem (2006), Antepüzümü (2005), Temiz ve Yeşilsu (2010), Dervişoğlu vd. (2004) ile Sarıŏlu Yavaş (2015) tarafindan sade dondurmalarda belirlenen değerlerin üzerindedir. $\mathrm{Bu}$ araştırmada dondurma örneklerinin üretiminde kullanılan dut kurusu tozu ve ceviz ezmesinin protein oranları sirasiyla \%2.764 ve \%14.316 olarak tespit edilmiştir. Dondurma örneklerinde belirlenen ortalama protein değerinin genel olarak literatürlerde belirlenen değerlerden yüksek olduğu (\%4.305) görülmüştür. Protein miktarındaki artışta ceviz ezmesi kullanımının etkili olduğu düşünülmektedir. 
Çizelge 3. Sade dondurma örneklerinin bazı fiziksel ve kimyasal özelliklerine ait literatürlerde geçen ortalama değerler

\begin{tabular}{|c|c|c|c|c|c|c|c|c|c|c|}
\hline & $\begin{array}{c}\text { KM } \\
(\%)\end{array}$ & $\begin{array}{c}\text { Yağ } \\
(\%)\end{array}$ & $\begin{array}{c}\text { Protein } \\
(\%)\end{array}$ & $\begin{array}{c}\text { Kül } \\
(\boldsymbol{\%})\end{array}$ & $\mathbf{p H}$ & $\begin{array}{c}\text { LA } \\
(\boldsymbol{\%})\end{array}$ & \multicolumn{2}{|c|}{ Şeker (\%) } & Referanslar \\
\hline $\mathbf{1}$ & 36.50 & 6.13 & - & - & - & - & - & - & - & Moriano ve Alamprese, 2017 \\
\hline $\mathbf{2}$ & 43.91 & 10.40 & - & - & 5.50 & 0.270 & - & - & - & Aboulfazli vd., 2016 \\
\hline $\mathbf{3}$ & 40.00 & 6.90 & 5.30 & 1.00 & 6.60 & - & - & - & - & Kavaz vd., 2015 \\
\hline $\mathbf{4}$ & 30.77 & 4.60 & - & - & 6.50 & - & - & - & 4.31 & Özdemir vd., 2015 \\
\hline $\mathbf{5}$ & 40.01 & 6.90 & 5.29 & 1.02 & 6.60 & 0.170 & - & - & - & Kavaz Yüksel, 2015 \\
\hline $\mathbf{6}$ & 35.40 & 4.87 & 3.73 & - & 6.59 & 0.210 & 25.77 & - & - & Sarığlu Yavaş, 2015 \\
\hline $\mathbf{7}$ & 34.56 & - & - & - & 6.19 & 0.260 & - & - & - & Akın ve Dasnik, 2015 \\
\hline $\mathbf{8}$ & 30.18 & - & - & 2.12 & 6.20 & 0.310 & - & - & - & Kırmac1 vd., 2014 \\
\hline $\mathbf{9}$ & 28.94 & 1.25 & 5.67 & - & 6.19 & 0.250 & - & - & - & Kesenkaş vd., 2013 \\
\hline $\mathbf{1 0}$ & 29.31 & 4.60 & 5.80 & 0.82 & 6.30 & 0.219 & - & - & - & Erkaya vd., 2012 \\
\hline $\mathbf{1 1}$ & - & - & - & - & 6.43 & 0.196 & - & - & - & Güven vd., 2010 \\
\hline $\mathbf{1 2}$ & 31.20 & 10.00 & 4.19 & 0.82 & 6.72 & 0.230 & 15.30 & 3.72 & 10.99 & Temiz ve Yeşilsu, 2010 \\
\hline $\mathbf{1 3}$ & 33.42 & - & - & - & 6.58 & 0.209 & - & - & - & Çelik vd., 2010 \\
\hline $\mathbf{1 4}$ & 37.90 & - & - & 1.18 & 6.31 & 0.260 & - & - & - & Karaman, 2009 \\
\hline $\mathbf{1 5}$ & 39.82 & 5.92 & 5.58 & - & 6.35 & 0.330 & - & - & - & Turgut ve Çakmakc1, 2009 \\
\hline $\mathbf{1 6}$ & 32.73 & 6.25 & 4.41 & - & - & - & - & - & - & Çeliker, 2008 \\
\hline $\mathbf{1 7}$ & 36.67 & - & - & - & - & - & - & - & - & Akın vd., 2007 \\
\hline $\mathbf{1 8}$ & 34.07 & 4.93 & 3.75 & 0.88 & 6.16 & 0.190 & - & - & - & Aliyev, 2006 \\
\hline $\mathbf{1 9}$ & 28.17 & 1.40 & 3.96 & - & 6.37 & - & - & - & - & Badem, 2006 \\
\hline $\mathbf{2 0}$ & 40.77 & 7.58 & 3.51 & - & 6.57 & 0.172 & - & - & - & Antepüzümü, 2005 \\
\hline $\mathbf{2 1}$ & 34.43 & 6.50 & 2.11 & 0.87 & 6.34 & 0.250 & - & - & - & Dervişoğlu vd., 2004 \\
\hline
\end{tabular}

LA: Laktik Asit, KM: Kurumadde, TŞ: Toplam Şeker, İ̧̧: İnvert Şeker, S:Sakkaroz

Bakkalbaşı vd. (2004), yapmış olduğu araştırmada dut kurusu tozunun kül miktarını \%2.40 ile \%3.44 arasinda, ortalama \%2.95 olarak tespit etmiştir. Özrenk vd. (2005), Erzincan yöresinden selekte etmiş oldukları ceviz örneklerinde kül oranının \%1.69-\%2.24 arasında olduğunu belirlemişlerdir. $\mathrm{Bu}$ çalışmada dondurma miksine ilave edilen dut kurusu tozu ve ceviz ezmesinin kül oranları sirasiyla $\% 1.487$ ve $\% 2.150$ olarak bulunmuştur. Araştırmada dondurma örneklerinde belirlenen ortalama kül değerinin (\%1.327) literatüre göre yüksek olmasının dondurma üretiminde yüksek oranda dut $(\% 20)$ ve ceviz (\%5) kullanımından kaynaklandığı söylenebilir.

Dondurma örneklerinin asitlik değeri \%laktik asit cinsinden ortalama $\% 0.338$ olarak, $\mathrm{pH}$ değerleri ise ortalama 6.310 olarak tespit edilmiştir. Sade ve çikolatalı dondurmalarda asitlik; miks içerisine giren ve yağsız kurumaddeyi oluşturan proteinlerden (kazein, albumin), sitratlar, fosfatlar ve süt içinde bulunan karbondioksitten meydana gelmektedir. Ayrıca süt içinde bulunan süt asidi bakterilerinin uygun isıda laktozu parçalamaları sonucunda da asitlik gelişebilmektedir (Yeşilsu, 2006). Dolayısıyla da farklı formülasyon içeriğine sahip ve farklı üretim metotları ile üretilmiş olan dondurmaların fizikokimyasal özellikleri de birbirlerinden farklı olabilmektedir. $\mathrm{Bu}$ araştırmada dondurma örneklerinde tespit edilen $\mathrm{pH}$ ve asitlik değerleri literatürlerde rapor edilen bulgularla benzerlik göstermektedir.

Dondurma örneğinin ortalama toplam şeker, invert şeker ve sakkaroz değerleri sırası ile $\% 17.495$, $\% 15.559, \% 1.914$ olarak tespit edilmiştir. Sarıoglu Yavaş (2015) yapmış olduğu çalışmada dondurma örneklerindeki toplam şeker oranının $\% 9.62$ ile $\% 25.77$ arasında değiştiğini, sade dondurmalarda bu oranın \%25.77 olduğunu bildirmiştir. Yapılan başka bir çalışmada üretilen sade dondurmaların toplam şeker, invert şeker ve sakkaroz içerikleri sırasıyla $\% 15.30, \% 3.72, \% 10.99$ olarak belirtilmiştir (Temiz ve Yeşilsu, 2010). Dondurma örneklerinde sakkaroz alternatifi olarak dut kurusu tozu kullanılması ile sade dondurma örneklerine oranla sakkaroz oranı düşmüş (\%1.914), invert şeker oranı (\%15.559) ise yükselmiştir.

$\mathrm{Bu}$ araştırma kapsamında, dut kurusu tozu ve ceviz ezmesi ilaveli dondurmalarda toplam kalori değeri $103.67 \mathrm{kcal}$ olarak hesaplanmıştır. Sarıoğlu Yavaş (2015) sakkaroz ve sakkaroza ikame olarak stevia kullandığı dondurmalarda kalori içeriğini sirasiyla $158.34 \mathrm{kcal}$ ve $111.69 \mathrm{kcal}$ olarak bildirmiştir.

Dondurmanın viskozite, hacim artışı, erime ve renk özelliklerine ilişkin ortalama değerler Çizelge 4'de verilmiştir. 
Çizelge 4. Dondurma örneklerinin bazı fiziksel özelliklerine ait ortalama değerler

\begin{tabular}{|c|c|c|c|c|c|c|c|c|c|}
\hline & \multirow{2}{*}{$\begin{array}{l}\text { Viskozite } \\
50 \text { rpm } \\
\text { (cp) }\end{array}$} & \multirow{2}{*}{$\begin{array}{c}\text { Hacim } \\
\text { Artışı }\end{array}$} & \multirow{2}{*}{$\begin{array}{c}\text { İlk } \\
\text { Damlama } \\
\text { (s) }\end{array}$} & \multirow{2}{*}{$\begin{array}{l}\text { Tam } \\
\text { Erime } \\
(s)\end{array}$} & \multicolumn{2}{|c|}{ Erime Oranı (\%) } & \multicolumn{3}{|c|}{ Renk } \\
\hline & & & & & 30. dk. & 60.dk & $L^{*}$ & $a^{*}$ & $b^{*}$ \\
\hline ORT & 2572 & 32.028 & 344 & 5297 & 78.431 & 85.680 & 39.90 & 1.93 & 12.40 \\
\hline SD & 14.142 & 3.398 & 38 & 488 & 3.600 & 2.607 & 5.71 & 0.30 & 1.56 \\
\hline
\end{tabular}

Dövülebilme yeteneği ile dondurmaya verilen havanın tutulması açısından karışımın belirli bir viskozite değerine sahip olması gerekir (Güven ve Akın, 1997). Dondurma örneklerinin ortalama viskozite değeri $\left(2572 \mathrm{cp}, 50 \mathrm{rpm}, 4^{\circ} \mathrm{C}\right)$, Kavaz vd. (2015), tarafindan sade dondurma örneklerinde bildirilen viskozite değerinden $\left(1470 \mathrm{cp}, 50 \mathrm{rpm}, 4^{\circ} \mathrm{C}\right)$ yüksek, Özdemir vd. (2015) tarafından sade dondurmalarda belirlenen viskozite değerinden (8480 cp, 50rpm) düşüktür.

Dut kurusu tozu ve ceviz ezmesi ilavesi ile elde edilmiş dondurma örneklerinin ortalama hacim artış1 oranı \%32.028 olarak belirlenmiştir. Hacim artış1, dondurmaya, yumuşak, homojen, ağızda kolay eriyebilir ve rahat tüketilebilir özellik kazandırmakla birlikte; dondurmanın dayanıklılığını, randımanını da arttırmaktadır. Temiz ve Yeşilsu (2010) değişik oranlarda pekmez ilave ederek yaptıkları dondurmalarda hacim artış oranının \%19.00-\%30.67 arasında değiştiğini, sade dondurmalarda ise bu oranın \%30.00 olduğunu ifade etmişlerdir. Dondurmada yağsız kurumadde, yağ ve sakkaroz düzeyi arttıkça hacim artışının azaldığ araştırmacılar tarafindan rapor edilmiştir (Temiz, 1994; Koçan ve Koçak, 2002; Temiz ve Yeşilsu, 2010). Christiansen vd. (1996) hacim artışı üzerine pH' daki azalışın, yağsız kurumadde ve yağ miktarından daha etkili olduğunu bildirmiştir. Benzer şekilde dondurma miksine ilave edilen bazı meyvelerin miks $\mathrm{pH}$ değerini düşürdüğü, böylece dondurma kitlesinde daha fazla köpürme ve daha fazla havanın tutulmasıyla hacim artışı sağlandığı bildirilmiştir (Temiz ve Yeşilsu, 2010; Kavaz Yüksel, 2015). Araştırmada sakkaroz ikame edici olarak dut kurusu tozunun kullanılması, dondurmada sakkaroz oranının (\%1.914) düşmesine böylelikle hacim artışının yükselmesine neden olmuş olabilir.

Dondurma örneklerinin ilk damlama, tam erime süresi ile 30 . ve 60 . dakikalarda belirlenen erime oranlar1 sırasıyla 344 s, 5297 s, \%78.431 ve \%85.680 olarak belirlenmiştir. Özdemir vd. (2015) sade dondurmalarda ilk damlama süresinin $1760 \mathrm{~s}$ ve tamamen erime süresinin de 9440 s olduğunu bildirmiştir. Dondurma miksine dahil olan bileşenlerin dolayısıyla miksin su tutma kapasitesini artıran etmenlerin, erime sürelerini uzattığ bildirilmektedir (Hwang vd., 2009; Kavaz vd., 2015). Yağ destabilizasyonu, kristal boyutu ve miks konsistensinin dondurmanın erime oranını etkilediği; yă globülleri arasında kısmi kaynaşma ve destabilizasyonu teşvik eden emülgatörlerin formu koruyarak erime hızını büyük ölçüde azalttığ 1 ifade edilmektedir (Muse vd., 2004; Bahramparvar ve Tehrani, 2011). Temiz (1994), krema ve yağsız süt tozu ilave ederek hazırladığı dondurmalarda yağ oranı arttıkça dondurmaların erime oranının düştüğünü bildirmiştir. Dondurma örneklerinin oda sıcaklığında stabilitesinin düşük olması, süt yağı yerine doymamış yă asitlerince zengin ceviz ezmesinin ikame edilmesi ve dondurma örneklerinin yăg oranının (\%2) oldukça düşük olmasından kaynaklanmış olabilir.

Dondurma örneklerinin ortalama renk değerleri, $L^{*}: 39.90-a^{*}: 1.93-b^{*}: 12.40$ olarak tespit edilmiştir. Dut kurusu tozu ve ceviz ezmesi kullanımı dondurmanın renk değerleri üzerine etkili olmuştur. $L^{*}$ (aydınlık) değeri, gıdalarda rengin açıklık ve koyuluğunun bir ölçüsü olup, $L^{*}$ değeri 0 'a yaklaştıkça siyah, 100'e yaklaştıkça ise beyaz rengin baskın olduğu anlaşılmaktadır. Rengin bir diğer kriteri olan $a^{*}$ değerinde ise, (+) $a^{*}$; kırmız1, (-) $a^{*}$; yeşili göstermektedir. $b^{*}$ değeri de rengin bir diğer kriteri olarak değerlendirilir ve $(+) b^{*}$; sarı, $(-) b^{*}$; mavi rengi ifade etmektedir. Bu çerçevede dut kurusu tozu ve ceviz ezmesi ilaveli dondurmaların renginin hafif mat, sarımsı-sütlü-kahve renkte olduğu söylenebilir.

Dondurma, üstün besleyici değere sahip gıda bileşenlerini yapısında bulundurması, beslenme ve toplumun büyük kesiminde beğeni ile tüketilmesine karşın, çoğu patojen mikroorganizmaların gelişimi için son derece uygun bir besi ortamı niteliğindedir. Dondurma, üretimi ve muhafazası sırasında mikrobiyolojik kontaminasyona çok elverişlidir. Gerekli hijyen kuralları uygulanmadan üretilen dondurmalarda, her türlü mikroorganizmanın gelişip çoğalabilmesi mümkün olabilmektedir.

Dut kurusu tozu ve ceviz ezmesi ilaveli dondurma örneklerinde mikrobiyolojik analizler sonucunda, TAMB sayısı $4.176 \mathrm{log} \mathrm{kob} / \mathrm{g}$ olarak 
saptanmış, örneklerde maya-küf, koliform grubu bakteri, E.coli ve $S$. aureus'a rastlanmamıştır. Dondurma örneklerinin, TS 4265 Nolu Dondurma Standardı ve Türk Gıda Kodeksi Dondurma Tebliği'nde öngörülen oranlara uygun olduğu anlaşılmıştır. Bu değerler, dondurma örneklerinin bakteriyolojik kalitesinin yüksek olduğu ve yüksek hijyen standartlarında üretim yapıldığını ve üretim sonrasında herhangi bir bulaşmanın söz konusu olmadığını göstermektedir.

Dondurma örneklerinin duyusal analiz sonuçlarına ait ortalama değerler Çizelge 5'de verilmiştir.

Çizelge 5. Dondurma örneklerinin duyusal analiz sonuçlarına ait ortalama değerler

\begin{tabular}{|c|c|c|c|c|c|c|}
\hline Özellik & $\begin{array}{c}\text { Renk ve } \\
\text { Görünüş }\end{array}$ & $\begin{array}{c}\text { Yapı ve } \\
\text { Kıvam }\end{array}$ & Tat ve Koku & Buzlu Yapı & Ağızda Erime & Sakızımsılık \\
\hline $\begin{array}{c}\text { Ortalama } \\
\text { Puan }\end{array}$ & 4.50 & 4.25 & 4.63 & 4.63 & 4.88 & 4.13 \\
\hline
\end{tabular}

Duyusal analiz sonuçlarına göre, dut kurusu tozu ve ceviz ezmesi ilavesi ile elde edilen dondurma örnekleri standartlarda belirtilen renk ve görünüş, yapı ve kıvam, tat ve koku nitelikleri bakımından alması gereken en az 4 puan sınırının üstünde puanlar alarak, panelistler tarafindan beğenilmiştir.

\section{SONUÇ}

Dondurma teknolojisi gıda ürünleri pazarında payı gün geçtikçe büyüyen önemli bir sektördür. Sağlıklı, fonksiyonel, farklı aroma ve kompozisyonlarda ürün eldesine oldukça elverişli ürün gruplarından biri olan dondurma, her yaştan bireyin severek tükettiği bir gıdadır. $\mathrm{Bu}$ araştırma kapsaminda, dut kurusu tozu ve ceviz ezmesinin dondurma üretiminde kullanımının kurumadde, protein, kül ve hacim artışı oranını arttırdığı tespit edilmiş, ayrıca dondurmada karakteristik bir tataroma ve renk oluşumu sağladığı gözlemlenmiştir. Dondurma örnekleri, tüm duyusal parametreler bakımından standartlarda belirtilen sınırın üzerinde puan almıştır. Sonuç olarak, dondurma miksine sakkaroz alternatifi olarak dut kurusu tozu ve süt yağına ikame olarak ceviz ezmesi ilavesinin dondurmanın fizikokimyasal ve duyusal nitelikleri bakımından pozitif etkiler sağladığı tespit edilmiş; sağlıklı beslenme açısından doğal ve düşük kalorili ürünleri tercih eden tüketicilere yönelik alternatif bir dondurma formülasyonu oluşturulmuştur.

\section{KAYNAKLAR}

Aboulfazli, F., Bakr Shori, A., Salihin Baba, A., 2016. Effects of the replacement of cow milk with vegetable milk on probiotics and nutrional profile of fermented ice cream. LWT-Food Science and Technology, 70: 261-270.

Akın, M.B., Akın, M.S., Kırmacı, S., 2007. Effects of inulin and sugar levels on the viability of yogurt and probiotic bacteria and the physical and sensory characteristics in probiotic ice cream. Food Chemistry, 104 (1): 93-99.

Akın, M.B., Dasnik, F., 2015. Effects of ascorbic acid and glucose oxidase levels on the viability of probiotic bacteria and the physical and sensory characteristics in symbiotic ice cream. Mljekarstvo, 65 (2):121-129.

Aliyev, C., 2006. Kefir ve Yaban Mersininin Dondurmanın Fizikokimyasal, Duyusal ve Mikrobiyolojik Özelliklerine Etkisi. Ondokuz Mayıs Üniv. Fen Bilimleri Enstitüsü Gıda Mühendisliği Anabilim Dalı, Yüksek Lisans Tezi, Samsun, $83 \mathrm{~s}$.

Alkan, M., Gültekin, O., 1996. Yüksek Fruktoz İçerikli Şuruplar. Dünya Gıda, 11: 16-17.

Anonim, 2004. Gıdaların Üretimi, Tüketimi ve Denetlenmesine Dair Kanun Hükmünde Kararnamenin Değiştirilerek Kabulü Hakkında Kanun, Resmi Gazete, Kanun No:5179.

Antepüzümü, F., 2005. Bal ve Glikoz Şurubu Kullanımının Kahramanmaraş Tipi Dondurmaların Kalitesi Üzerine Etkileri. Çukurova Üniv. Fen Bilimleri Enstitüsü Gıda Mühendisliği Anabilim Dalı, Yüksek Lisans Tezi, Adana, $57 \mathrm{~s}$.

Arbuckle, W. S., 1986. Ice Cream, 4th Ed. Van Nostrand Reinhold, New York.

Badem, A., 2006. Keçi Boynuzu Pekmezli Dondurma Üretiminde Kullanilan Karragenan, Ksantan ve Keçiboynuzu Zamklarının Dondurmaların Kaliteleri Üzerine Etkisi. Akdeniz Üniv. Fen Bilimleri Enstitüsü Gıda Mühendisliği Anabilim Dalı, Yüksek Lisans Tezi, Antalya 80s.

Bahramparvar, M., Mazaheri Tehrani, M., 2011. Application and Functions of Stabilizers in Ice Cream. Food Reviews International, 27: 389-407.

Bakalbaşı, E, Yemiş, O, Artık, N., 2004. Dut Kurusunun Fiziksel ve Kimyasal Özellikleri İle Ekstraksiyon Koşullarının Belirlenmesi. Gida, 29 (3): 203-209.

Baysal, A.,2009. Beslenme. 12. Baskı. Hatipoğlu Yayınları:93, Ders Dizisi Kitabı:26, 560s, Ankara.

Bodyfelt, F.W., Tobias, J., Trout, G.M., 1988. The Sensory Evaluation of Dairy Products. AVI Book, New York, 166226.

Christiansen, P.C., Edelsten, D., Kristiansen, J. R., Nielsen, E.W., 1996. Some properties of ice cream containing Bifidobacterium bifidum and Lactobacillus acidophilus. Milchwissenschaft, 51 (9):502-505.

Colombini, M.,Vanoni, M.C., Amelotti, G., 1979. Oliodi Noci, Nocciole, Mandorle, Avocado: Compozisione Sterolica. Rivista italiana dele sostanze grasse, 56: 392-393.

Cotrell, J. F. L., Pass, G., Phillips, G.O., 1979. Assesment of Polysaccharides as Ice Cream Stabilizers. Journal of the Science of Food and Agriculture, 30: 1085-1089.

Çelik, Ş., Cankurt, H., Doğan, C.,2010. Safran İlavesinin Sade Dondurmanın Bazı Özelliklerine Etkisi. Gıda, 35 (1): 33-39.

Çeliker, B.M., 2008. Alıç Meyvesinin Pekmeze İşlenerek Dondurma Üretimine İlavesiyle Dondurmanın Kalite Kriterleri. Afyon Kocatepe Üniv. Fen Bilimleri Enstitüsü 
Gıda Mühendisliği Anabilim Dalı, Yüksek Lisans Tezi, Afyon, 71s.

Dervişoğlu, M., Hurşit, K.A., Yazıcı, F., 2004. Yağsız Soya Ununun Vanilyalı Dondurmaların Fiziksel ve Duyusal Özelliklerine Etkisi. Gıda, 29 (6):443-449.

Erkaya, T., Dağdemir, E., Şengül, M., 2012. Influence of Cape gooseberry (Physalisperuviana L.) addition on thechemical and sensory characteristics and mineral concentrations of ice cream. Food Research International, 45: 331-335.

Goff, H D, Verespei, E., Smith, A.K., 1999. A study of fat and air structures in ice cream. İnternational Dairy Journal, 9: 817829.

Güven, M., Akın, M.S.,1997. Farklı oranlarda süttozu ilave edilerek üretilen dondurmaların fiziksel ve duyusal özellikleri. Çukurova Üniv. Ziraat Fak. Derg.12 (4): 11-20.

Güven, M., Karaca, B.O., Yaşar, K., 2010. Düşük Yağ Oranlı Kahramanmaraş Tipi Dondurma Üretiminde Farklı Emülgatörlerin Kullanımının Dondurmaların Özellikleri Üzerine Etkileri. G1da, 35 (2): 97-104.

Harrigan, W.F.,1998. Laboratory Methods in Food Microbiology, Academic Press, San Diego, US, 519s.

Hwang, J.Y.,Shyu, Y.S., Hsu, C.K., 2009. Grape winelees improves the rheological and adds antioxidant propertiesto ice cream. LWT- Food Science and Technology, 42 (1):312-318 .

IDF (International Dairy Federation), 1993. Standart Method 20B:Milk Determination of Nitrogencontent, Brussels, Belgium.

IDFA, 2016. http://www.idfa.org/news-views/media-kits/icecream/ice-cream-labeling (Erișim tarihi: 25.12.2016)

Karaman, S., 2009. Çay veya Bazı Bitki Çayları ile Aromatize Edilmiş Dondurma Üretim Olanaklarının Araştırılması. Erciyes Üniv. Fen Bilimleri Enstitüsü Gıda Mühendisliği Anabilim Dalı, Yüksek Lisans Tezi, Kayseri, 99s.

Kavaz, A., Yüksel, M., Dağdemir, E.,2015. Determination of certain quality characteristics, thermal and sensory properties of ice creams produced with dried Besni grape (Vitisvinifera L.). International Journal of Dairy Technology, 68:1-7.

Kavaz-Yüksel, A.,2015. Theeffects of blackthorn (Prunus spınosa L.) addition certain quality characteristics of ice cream. Journal of Quality, 38 (6): 413-421

Kesenkaş, H., Akbulut, N., Yerlikaya, O., Akpınar, A., Açu, M., 2013. Kefir Dondurması Üretiminde Soya Sütünün Kullanım Olanakları Üzerine Bir Araştırma. Ege Üniv. Ziraat Fak. Derg., 50 (1):1-12.

Kırdar, S., 2003. Burdur İlinde Satılan Dondurmaların Bazı Nitelikleri Üzerine Araştırmalar. Gıda, 28 (2):175-181.

Kırmacı, H.A., Kuşcu, H., Atasoy, F., 2014.Farklı Oranlarda Prebiyotik Lif İçeren Stevia Özü Illavesinin Probiyotik Dondurmanın Kalite Özellikleri Etkisi. Harran Tarım ve Gıda Bilimleri Derg.,18 (3): 48-59.

Koçan, D., Koçak, C., 2002. Vanilyalı Dondurma Üretiminde Quest Admul MG 4143 Emülgatörünün Farklı Kullanım Olanaklarının Dondurma Niteliklerine Etkileri. Gıda, 35 (2): 97-104.

Kurt, A., 1990. Süt Teknolojisi. Atatürk Üniv. Yayınları No:573, 398s, Erzurum.

Kurt, A., Çakmakçı S., Çağlar A., 2012. Süt ve Mamulleri Muayene Analiz Metotları Rehberi. 12. Baskı. Atatürk Üniv. Ziraat Fak. Yayınları No:18, 254s, Erzurum.
Merck., 2005. Gıda Mikrobiyolojisi Uygulamaları. Ed: Prof. Dr. A. Kadir Halkman, 368s, Ankara.

Metin, M., 2012. Süt ve Mamulleri Analiz Yöntemleri. Ege Üniversitesi Basımevi, 439s, İzmir.

Moriano, M.E., Alamprese, C., 2017. Honey, trehalose and erythritol as sucrose alternative sweeteners for artisanal ice cream A pilot study. LWT-Food Science and Technology,75: 329-344.

Muse, M.R.,Hartel, R.W., 2004. Ice cream structural elements that affect melting rate and hardness. Journal of Dairy Science, 87 (1): 1-10

Özdemir, C., Arslaner, A., Özdemir, S., Allahyari, M., 2015. The production of ice cream using stevia as a sweetener. Journal of Food Sci Technol, 52 (11):7545-7548.

Özrenk, K., Güleryüz, M., Kazankaya, A., Balta, F.M., Yarılgaç, T., 2005. Erzincan Yöresinden Selekte Edilmiş Ceviz (Juglansregia L.) seleksiyonlarının Bazı Kimyasal Özelliklerinin Belirlenmesi. Bahçe Ceviz, 34 (1): 171-175.

Pereira, A.P., Pereira, J.A., Bento, A., Estevinho, M.L., 2008. Microbiological characterization of table olives commercialized in Portugal in respect to safety aspects. Food and Chemical Toxicology, 46: 2895-2902.

Pichhardt, K., 2004. Gıda Mikrobiyolojisi ve Gıda Endüstrisi İçin Temel Esaslar ve Uygulamalar. Literatür Yayınları Manisa, 176-178.

Sarıoglu Yavaş, A., 2015. Düşük Kalorili Dondurma Üretiminde Doğal Tatlandırıcı Olarak Stevya Ekstraktı Kullanımının Ürün Kalite Kriterleri Üzerine Etkisi. Ege Üniv. Fen Bilimleri Enstitüsü Gıda Mühendisliği Anabilim Dalı, Doktora Tezi, İzmir, 127s

Tatini, R.S., Hoover, G.D., Lachica, F.V.R., 1984. Methods for the isolation and enumeration of Staphylococcus aureus In: M.L. Speck (Ed.), Compendium of Methods for the Microbiological Examination of Foods. APHA, Washington, D.C. pp. 411-427.

Temiz, H., 1994, Krema ve Yağsız Süttozu Katılarak Bileşimi Zenginleştirilmiş İnek Sütlerinden İşlenen Dondurmaların Bazı Fiziksel, Kimyasal ve Duyusal Nitelikleri Üzerine Bir Araştırma. Ondokuz Mayıs Üniv. Fen Bilimleri Enstitüsü Gıda Mühendisliği Anabilim Dalı, Yüksek Lisans Tezi, Samsun, 74s.

Temiz, H.,Yeşilsu, A.F., 2010. Effect of pekmez addition on the physical, chemical, and sensory properties of ice cream. Czech Journal of Food Science, 28 (6):538-546.

Turgut, T., Cakmakcı, S., 2009. Investigation of the possible use of probiotics in ice cream manufacture. International Journal of Dairy Technology, 62 (3): 444-451.

Yeşilsu A.F., 2006. Dondurmanın Fiziksel, Kimyasal ve Duyusal Özellikleri Üzerine Bazı Pekmez Çeşitlerinin Etkisi. Ondokuz Mayıs Üniv. Fen Bilimleri Enstitüsü Gıda Mühendisliği Anabilim Dalı, Yüksek Lisans Tezi, Samsun, $100 \mathrm{~s}$.

Yiğit, A., Ertürk, Ü., Korukluoğlu M., 2005. Fonksiyonel bir gida: Ceviz. Bahçe Ceviz, 34 (1): 163-169.

Yöney, Z., 1968. Dondurma Teknolojisi Atatürk Üniv. Ziraat Fak. Süt ve Mamulleri Kürsüsü, Yayın No: 360. Atatürk Üniv. Basımevi. 110s. 